\title{
Natural Seed Limitation and Effectiveness of Forest Plantations to Restore Semiarid Abandoned Metal Mining Areas in SE Spain
}

\author{
Marta Bindang Oná ${ }^{1,2}$, Marta Goberna $^{1}$ and Jose Antonio Navarro-Cano ${ }^{1, *(D)}$ \\ 1 Department of Environment and Agronomy, Centro Nacional Instituto de Investigación y Tecnología Agraria \\ y Alimentaria, INIA-CSIC, Ctra. de la Coruña, km 7.5, 28040 Madrid, Spain; \\ maronabindang@gmail.com (M.B.O.); marta.goberna@inia.es (M.G.) \\ 2 Facultad de Medio Ambiente, Universidad Nacional de Guinea Ecuatorial (UNGE), Hassan II s/n, \\ Malabo 661, Guinea Ecuatorial \\ * Correspondence: jantonio.navarro@inia.es
}

Citation: Oná, M.B.; Goberna, M.; Navarro-Cano, J.A. Natural Seed Limitation and Effectiveness of Forest Plantations to Restore Semiarid Abandoned Metal Mining Areas in SE Spain. Forests 2021, 12, 548. https:// doi.org/10.3390/f12050548

Academic Editor: Rodney Will

Received: 17 March 2021

Accepted: 23 April 2021

Published: 28 April 2021

Publisher's Note: MDPI stays neutral with regard to jurisdictional claims in published maps and institutional affiliations.

Copyright: (c) 2021 by the authors. Licensee MDPI, Basel, Switzerland. This article is an open access article distributed under the terms and conditions of the Creative Commons Attribution (CC BY) license (https:/ / creativecommons.org/licenses/by/ $4.0 /)$.

\begin{abstract}
The natural regeneration of forests in mining areas is typically hampered by edaphic stress. Semiarid conditions add a climatic stress that challenges the restoration of these harsh ecosystems. This is the case of Tetraclinis articulata (Vahl) Masters mixed forests in the Western Mediterranean region colonizing mining structures abandoned three decades ago. We studied the factors controlling the natural establishment of nine shrub and tree species key in these forests in eight metal mine tailings in SE Spain. In addition, we assessed the success of reintroducing 1480 individuals of the nine species 15 months after planting in one of the tailings. Specifically, we analyzed the effect of (i) species identity in terms of sapling survival, growth, nutritional status and metal bioaccumulation, and (ii) adding organic amendments into the planting holes on the same parameters. Our results indicated that natural colonization is a recent process, with seedling cohorts that vary up to two orders of magnitude among species and a practical absence of adult plants in most species excepting T. articulata. We identified seed limitation as a key factor controlling seedling density, which was significantly explained by the distance from the border of the tailing to the closest adult out of the tailing. Soil metal concentration did not have any explanatory power on the density of naturallyestablished seedlings, whereas soil fertility was relevant only for Rhamnus lycioides L. Overall survival of planted individuals was over $80 \%$, survival and growth remarkably differing among species. Organic amendments had neutral or negative effects on plant survival, but significantly increased the growth of survivors despite their modest effects on leaf nutrient contents. Most species showed high metal bioaccumulation, which was exacerbated by organic amendments. We discuss how biodiversity conservation programs can benefit from the affordable and successful plantation of stress-tolerant local species, but come at the expense of potential metal transfer through trophic webs.
\end{abstract}

Keywords: composted waste; ecological restoration; local species; polluted soil; Mediterranean forest; metal bioaccumulation; organic amendment; Olea europaea L.; shrub

\section{Introduction}

Mining is one of the most environmentally damaging activities, with long-term negative effects on ecosystems due to soil denudation and pollution, as well as exhaustion of soil fertility and productivity [1]. In Europe, mining industry is responsible for $60 \%$ of contaminated lands, and only in 5\% of all cases restoration or rehabilitation programs have been carried out [2]. The most limiting situation that hinders both the natural recolonization and ecological restoration of these areas occurs when edaphic and climatic stresses concur [3]. That is the case of mining areas in drylands. Metal mining generates barren substrates of high soil toxicity, physical instability, as well as water and temperature stress. These factors hamper biological colonization and the promotion of basic ecosystem functions, such as 
organic matter decomposition and nutrient cycling driven by decomposer activity [4] or the resistance to disturbances and ecosystem stability provided by the plant cover [5].

Forest restoration programs in reclaimed metal mine soils have been described in North America and Central-Europe [1,6-9]. These works from humid and cold climates show that tree plantations on mine tailings can achieve growths similar to adjacent mineunaffected areas in the mid- to long-term, with positive effects on different goods and services, including erosion control, carbon sequestration in soils and biomass or wood production. Nevertheless, metal concentration in the soil profiles of revegetated tailings suggests potential metal transfer to the food chain that could have toxic effects on different trophic levels [1]. In arid and semiarid areas, available examples of rehabilitation programs that included revegetation actions in mine soils are based mainly on the seeding or planting of species with short life forms such as herbs, grasses and shrubs [10-13]. However, similarly to what has been observed in humid and cold climates, planted species in mining soils from drylands can uptake high metal concentrations, even after extensive sealing with a non-polluted soil layer [14]. In order to decrease the metal mobility together with the physical and chemical infertility of these mine soils several authors have assessed the use of organic amendments [15-17]. These amendments can trigger natural plant establishment and the survival and growth of planted species [18]. Moreover, the use of amendments allows transforming an organic waste, as sewage sludge or animal manure, into a nutrient source for microbial and plant communities [17]. Nevertheless, some authors have observed an enhanced mobility of several metal and metalloids (hereafter metal(loid)s), e.g., As, $\mathrm{Cu}$ and $\mathrm{Pb}$, through weathering and decomposition of added organic matter depending on soil $\mathrm{pH}[11,19-21]$.

Together with the improvement of soil properties, the selection of suitable plant species is fundamental to guarantee the success of restoration programs in abiotically stressful areas [22,23]. Plant selection for plantation in mine tailings has evolved from the use of model species towards the use of local species adapted to barren substrates that are able to tolerate (but not accumulate) metal(loids) $[11,19,24,25]$. This search can be especially beneficial in biodiversity hot spots where ecosystems have been historically occupied by the mining industry and nowadays require ecological restoration programs that in turn can benefit from the local biodiversity potential.

The Cartagena-La Unión mining district (SE Spain) has been one of the historical hot spots of metal-mining industry in Europe [26]. Nowadays, once the mining activity ceased approximately thirty years ago, most mine tailings derived from the metal-concentration process are abandoned and shape young ecosystems characterized by the depletion of both supporting and regulatory ecosystem services. As biological colonization is hampered by mine wastes, ecosystem functions delivered by soils are severely damaged [3,27]. All these factors pose a threat for environmental and human health through the wind and water transport of toxic particles from the tailings to natural or urban neighboring areas [28-31]. Moreover, they pose a challenge for the use of conventional restoration methodologies [26,32]. In SE Spain, these tailings resemble micro-deserts surrounded by a semiarid mixed forest landscape that is legally protected under the name of the European priority habitat Tetraclinis articulata forests (code 9570) [33,34].

Current environmental laws require developing management programs aimed at restoring the original habitats usurped by the mining activity [5]. A first pilot restoration project of this mixed forest in a mine tailing located within a Natura 2000 Site was carried out in January 2018. The restoration program included the establishment of nine of the main species of this forest (Tetraclinis articulata, Rhamnus lycioides, Pistacia lentiscus L., Quercus coccifera L., Chamaerops humilis L., Olea europaea var sylvestris Brot., Periploca angustifolia Labill., Maytenus senegalensis (Lam.) Exell, and Withania frutescens (L.) Pauquy) in combination with organic amendments aimed at relieving the edaphic stress during the establishment stage of planted species. Under the premise that different species may have contrasted colonization trends in these harsh ecosystems, we assessed: (i) the role of seed limitation and edaphic stress in the natural colonization of the target species 
in mine tailings, and (ii) the effect of species identity and organic amendments on the survival, growth, nutritional status and metal bioaccumulation in planted saplings of the same species. The results may help optimize the management of relevant plant species in restoration programs of other mining areas within the Western Mediterranean.

\section{Material and Methods}

\subsection{Study Area}

The study system is the Cartagena-La Unión Mining District (Murcia, Spain). The climate is semi-arid Mediterranean with $17.9{ }^{\circ} \mathrm{C}$ mean annual temperature, $316.3 \mathrm{~mm}$ mean annual precipitation and $762.2 \mathrm{~mm}$ evapotranspiration (data for 2005-2015 period obtained from the closest meteorological station provided by the public agrometeorological information system of Murcia: SIAM). Metal mine tailings of the area have contrasted soil properties due to a different chemical content of the original ores from which they originated [26]. The surrounding landscape is dominated by a mixed forest with abundant Iberian-North African shrub species and local endemics. This Tetraclinis articulata forest has ideally an open tree canopy dominated by Pinus halepensis Mill. and T. articulata. Several Mediterranean and subtropical shrubs (C. humilis, P. lentiscus, Rhamnus sp. pl., M. senegalensis, P. angustifolia, W. frutescens) shape the woody understory with a very diversified herbaceous ground [35].

We assessed the natural colonization of the nine target species shaping the Tetraclinis articulata mixed forest in eight mine tailings within the Mining District (Table S1, Figure S1). A subsequent plantation was carried out in one of these tailings (Tailing Number 5), which is located within the European Natura 2000 Site Calblanque, Monte de las Cenizas y Peña del Águila. This site holds one of the best examples of this semi-arid Western Mediterranean mixed forest. The tailing occupies 1.8 ha and was abandoned 25 years ago, when the natural colonization process started leading to the current sparse patchy vegetation cover with some adult $P$. halepensis, Tamarix canariensis Willd., Dorycnium penthaphyllum Scop., Piptatherum miliaceum (L.) Coss. and Limonium carthaginense (Rouy) C.E. Hubb. \& Sandwith. These species in turn facilitate the recruitment of several species of the Tetraclinis forest underneath their canopies [36].

\subsection{Natural Plant Colonization in the Mine Tailings}

We sampled adults and seedlings of all nine target species in Winter-Spring 2015. We detected adults by in situ visual inspection of the whole tailing area. We quantified seedlings by systematically sampling the number of individuals growing in 576 plots, with a minimum of 30 plots per species in a tailing, including multispecific plant patches and (an equivalent area in) the open space surrounding each patch. The sampled plots averaged $183 \mathrm{~cm}$ diameter (min and max values from 50 to $835 \mathrm{~cm}$ depending on the patch size). We estimated the density of each species per hectare by extrapolating the sampled surface to the whole tailing considering the proportion of patches and open spaces. We quantified the area occupied by patches and open spaces in each tailing using high-resolution (0.25-0.50 m) aerial digital orthophotographs (http:/ / sitmurcia.carm.es / (accessed on: 3 September 2020)).

To assess the role of seed limitation in hampering the natural colonization of the tailings, we measured the distance from the border of the tailing to the closest adult out of the tailing for each target species. Adults were detected by inspection of the surrounding area to a distance of up to $2 \mathrm{~km}$ from the border.

Soil properties in each tailing were analyzed from six composite surface samples $(0-5 \mathrm{~cm})$ randomly distributed across the tailing surface. Each composite sample was composed of five mixed subsamples (ca. $200 \mathrm{~g}$ each) that were collected in the center and cardinal points within a $1 \mathrm{~m}^{2}$ plot. Soil samples were transported to the laboratory and sieved ( $\leq 2 \mathrm{~mm}$ ). Soil gravimetric humidity $(\mathrm{GH}), \mathrm{pH}$, electrical conductivity (EC), total organic carbon (TOC) and total nitrogen (N) were measured using standard procedures as described in [37]. Soil pH and EC were measured in a suspension in water (1:2.5 and 
1:5 $w / v$, respectively). TOC and N were quantified using a TruSpec Analyser (FLASH EA 1112 Series, LECO Corporation, St. Joseph, MI, USA). TOC was quantified after a $55^{\circ} \mathrm{C}$ acidic $(\mathrm{HCl})$ treatment of the samples. Total contents of $\mathrm{P}, \mathrm{K}$ and the metal(oid)s As, $\mathrm{Cd}, \mathrm{Cu}, \mathrm{Fe}, \mathrm{Mn}, \mathrm{Pb}$ and $\mathrm{Zn}$ were determined by digestion with $\mathrm{HNO}_{3}$ and $\mathrm{H}_{2} \mathrm{O}_{2}$, using an Ultraclave microwave digestion system (Milestone, Milan, Italy) followed by analysis by Inductively Coupled Plasma Optical Emission Spectroscopy (ICAP 6500 ICPOES Spectrometer, Thermo Fischer Scientific, Waltham, MA, USA). Soil data are expressed on an oven-dried $\left(105^{\circ} \mathrm{C}\right)$ weight basis (Table 1$)$.

\subsection{Plantation of the Tetraclinis Mixed Forest in a Mine Tailing}

In January 2018, 1480 individuals belonging to the nine target species were planted within the framework of the LIFE Project "Conservation of Habitat 9570 *, Forests of Tetraclinis articulata in the European Continent" (Figure S2). Preparation works included manually digging $1480(40 \mathrm{~cm}$ wide $\times 40 \mathrm{~cm}$ depth) holes. In half of all holes, we added an organic amendment including six liters of a 1:1 mix of composted organic waste and pine wood chips both from local sources. The composted waste came from a local solid

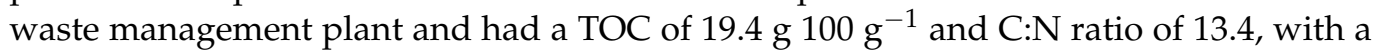
low quality due to its metal concentration and EC (see Table 1). The other half received no amendment to serve as controls. One year-old seedlings from a local nursery were planted randomly across the tailing. The number of planted seedlings per species was 412 (T. articulata), 144 (C. humilis, P. lentiscus, R. lycioides, M. senegalensis, P. angustifolia and Olea europaea var. sylvestris) and 102 (W. frutescens and Q. coccifera) attending to their natural density out of the tailings. Each plant was protected with a plastic anti-herbivore mesh ( $50 \mathrm{~cm}$ height $\times 25 \mathrm{~cm}$ wide) as we observed grazing by rabbits. A natural rainfall $\left(27 \mathrm{~L} \cdot \mathrm{m}^{-2}\right)$ occurred during the plantation week, and thus artificial watering was delayed until May and July 2018, with 8 L water per hole and event.

We assessed the effect of both plant species identity and organic amendment addition on the survival, growth, nutritional status and metal(oid) bioaccumulation in all planted species 15 months after the plantation. In March 2019, survival was estimated in the field on a set of 319 seedlings that were randomly selected across the tailing and labelled immediately after the plantation. The sampling size for each species was approximately proportional to the planting size (Table S3). Growth was quantified for the same set of plants as the height and trunk diameter at $1 \mathrm{~cm}$ over the soil surface. Nutritional status and metal(oid) content of the seedlings were assessed in leaf samples collected in a minimum of five individuals per species and treatment (organic amendment vs. control) that were randomly selected and georeferenced with a GPS Garmin Oregon 750t. At least three new leaves were collected per individual and transported to the laboratory. Leaf $C$ and $\mathrm{N}$ were quantified as for soils from $1 \mathrm{~g}$ of fresh ground leaves. Other nutrients $(\mathrm{P}, \mathrm{K})$ and metal(oid)s (As, Cd, Cu, Fe, Mn, $\mathrm{Pb}$ and $\mathrm{Zn}$ ) were quantified in ground and digested samples, and analyzed by ICP-OES as for soils. Plant data are expressed on an oven-dried $\left(65^{\circ} \mathrm{C}\right)$ weight basis. 


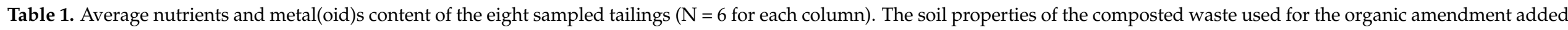

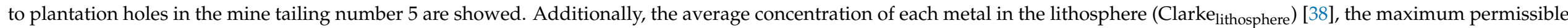
concentrations in soils of the Netherlands (MPC) [39] and the maximum recommended values (MRV) in forest soils in Andalucía (Spain) [40] are showed.

\begin{tabular}{|c|c|c|c|c|c|c|c|c|c|c|c|c|}
\hline $\begin{array}{l}\text { Mine Tailing } \\
\text { Soil Properties }\end{array}$ & 1 & 2 & 3 & 4 & 5 & 6 & 7 & 8 & $\begin{array}{l}\text { Composted } \\
\text { Waste }\end{array}$ & Clarke $_{\text {lithosphere }}$ & MPC & MRV \\
\hline TOC $\left(\mathrm{g} 100 \mathrm{~g}^{-1}\right)$ & 0.836 & 0.664 & 0.670 & 0.542 & 0.592 & 0.782 & 0.670 & 0.153 & 19.42 & & & \\
\hline $\mathrm{N}\left(\mathrm{g} 100 \mathrm{~g}^{-1}\right)$ & 0.054 & 0.047 & 0.079 & 0.045 & 0.087 & 0.044 & 0.045 & 0.018 & 1.89 & & & \\
\hline $\mathrm{P}\left(\mathrm{g} 100 \mathrm{~g}^{-1}\right)$ & 0.023 & 0.001 & 0.044 & 0.001 & 0.043 & 0.001 & 0.026 & 0.005 & 0.35 & & & \\
\hline $\mathrm{K}\left(\mathrm{g} 100 \mathrm{~g}^{-1}\right)$ & 0.187 & 0.255 & 0.327 & 0.093 & 0.486 & 0.222 & 0.247 & 0.071 & 0.71 & & & \\
\hline $\mathrm{pH}$ & 7.92 & 7.86 & 7.05 & 7.69 & 6.69 & 7.31 & 7.66 & 6.68 & 6.5 & & & \\
\hline As $\left(\mathrm{mg} \mathrm{kg}^{-1}\right)$ & 355 & 167 & 232 & 120 & 260 & 153 & 197 & 93 & $<0.01$ & 5.6 & 34 & 100 \\
\hline $\mathrm{Cd}\left(\mathrm{mg} \mathrm{kg}^{-1}\right)$ & 10.8 & 36.0 & 2.3 & 37.0 & 23.3 & 20.7 & 15.2 & 15.6 & 2.7 & 0.09 & 1.6 & 15 \\
\hline $\mathrm{Cu}\left(\mathrm{mg} \mathrm{kg}^{-1}\right)$ & 19.2 & 86.5 & 35.0 & 106.6 & 94.2 & 404.0 & 38.0 & 46.8 & 110.0 & 27 & 40 & 500 \\
\hline $\mathrm{Fe}\left(\mathrm{mg} \mathrm{kg}^{-1}\right)$ & 124,554 & 129,326 & 97,636 & 184,264 & 95,165 & 144,816 & 136,255 & 146,313 & 9689 & 465 & & \\
\hline $\operatorname{Mn}\left(\mathrm{mg} \mathrm{kg}^{-1}\right)$ & 4529 & 5246 & 2413 & 9086 & 1695 & 7386 & 6189 & 8148 & 186 & 7.7 & & \\
\hline $\mathrm{Zn}\left(\mathrm{mg} \mathrm{kg}^{-1}\right)$ & 4851 & 13,288 & 638 & 14,619 & 10,681 & 10,405 & 6653 & 8082 & 272 & 75 & 160 & 1000 \\
\hline
\end{tabular}




\subsection{Statistical Analyses}

\subsubsection{Natural Colonization in the Mine Tailings}

By taking the tailing as a replicate we analyzed the differences in the colonization pattern among plant species in the eight tailings by generalized linear models (GLM), including the species identity as a fixed factor and the seedling density as the response variable. We used a quasi-Poisson error distribution to account for data overdispersion with the glm function in the stats package for R version 4.0.2 [41].

We assessed two factors as potential drivers of the colonization patterns observed: (i) the distance from the tailing border to the closest adult detected in the surrounding landscape, and (ii) the soil properties within the tailing. We used them both as main predictors of seedling density for each species in GLMs with a quasi-Poisson error distribution.

We reduced the soil properties within the tailings to two main variables by performing two principal component analyses (PCA) that respectively included variables related to soil fertility (TOC, N, P and K) and metal(oid) content (As, Cd, Cu, Fe, Mn, $\mathrm{Zn}$ and $\mathrm{Pb}$ ). The first PC of 'soil fertility PCA' was inversely correlated with TOC, N, P and K and explained $71 \%$ of variance, whereas PC1 of 'metal(oid) PCA' was inversely correlated with all the variables excepting As and explained $64 \%$ of variance (Figure S3). Analyses were performed with the prcomp function in R.

\subsubsection{Plantation of the Tetraclinis Mixed Forest in Mine Tailing}

We assessed the effect of species identity and organic amendment addition on planted seedling survival using a GLM with a binomial error distribution. We analyzed speciesby-species effects by GLMs including organic amendment as fixed factor using the $\mathrm{glm}$ function in the stats package for R. To analyze seedling growth, we performed GLMs as above to explain two dependent variables (seedling height and trunk diameter) with Gaussian error distributions.

We tested the existence of spatial autocorrelation in leaf nutrient and metal(oid)s contents of planted individuals by calculating Mantel correlations between geographic and chemical (Euclidean) distance matrices with 999 iterations. We used the vegdist and mantel functions in the vegan package for R [42].

The overall effects of species identity and organic amendment addition on leaf macronutrients (C, N, P, K, C:N ratio) and metal(oid) bioaccumulation (As, $\mathrm{Cd}, \mathrm{Cu} \mathrm{Fe}, \mathrm{Mn}$, $\mathrm{Pb}$ and $\mathrm{Zn}$ ) were assessed by GLMs with a Gaussian error distribution as above. We also performed specific GLMs per species as above. Dependent variables were log-transformed in all models to stabilize the variance.

\section{Results}

\subsection{Natural Plant Colonization in the Mine Tailings}

The nine target species showed different seedling density in the eight tailings, whereas the density of adults was almost negligible in most species. Overall, seedlings showed a density of (mean \pm SE) $708 \pm 311$ plants $\cdot$ ha $^{-1}$ whereas adults were just $0.7 \pm 0.4$ plants ha $^{-1}$. Seedlings of R. lycioides and P. lentiscus had the highest densities, being on average above 200 plants.ha $^{-1}$ (Figure 1). They were followed by P. angustifolia and T. articulata whereas species such as O. europaea, C. humilis or Q. coccifera had densities below 2 seedlings.ha ${ }^{-1}$.

The distance from the tailing border to the closest adult of each species out of the tailing was a main predictor of seedling density. The effect was negative, that is, the more distant the closest individual in the tailing's surroundings the lower the species density within the tailing (GLM, Estimate $=-0.03, t=-2.73, p=0.008$ ) (Figure 2). The studied species had roughly $100 \mathrm{~m}$ as a critical distance for the colonization from external adult plants. The analysis of the joint effects of the distance to the closest adult and the soil properties of the tailing showed that the seedling densities of R. lycioides, P. lentiscus and $P$. angustifolia were mainly explained by the distance to the seed source, whereas soil fertility exclusively exerted a positive effect on $R$. lycioides (Table S2). We did not find a significant effect of the content of metal(oid)s in soil on the density of seedlings for the five analyzed 
plant species (Table S2). For the other four studied species we could not analyze their effect due to their low presence in the tailings.

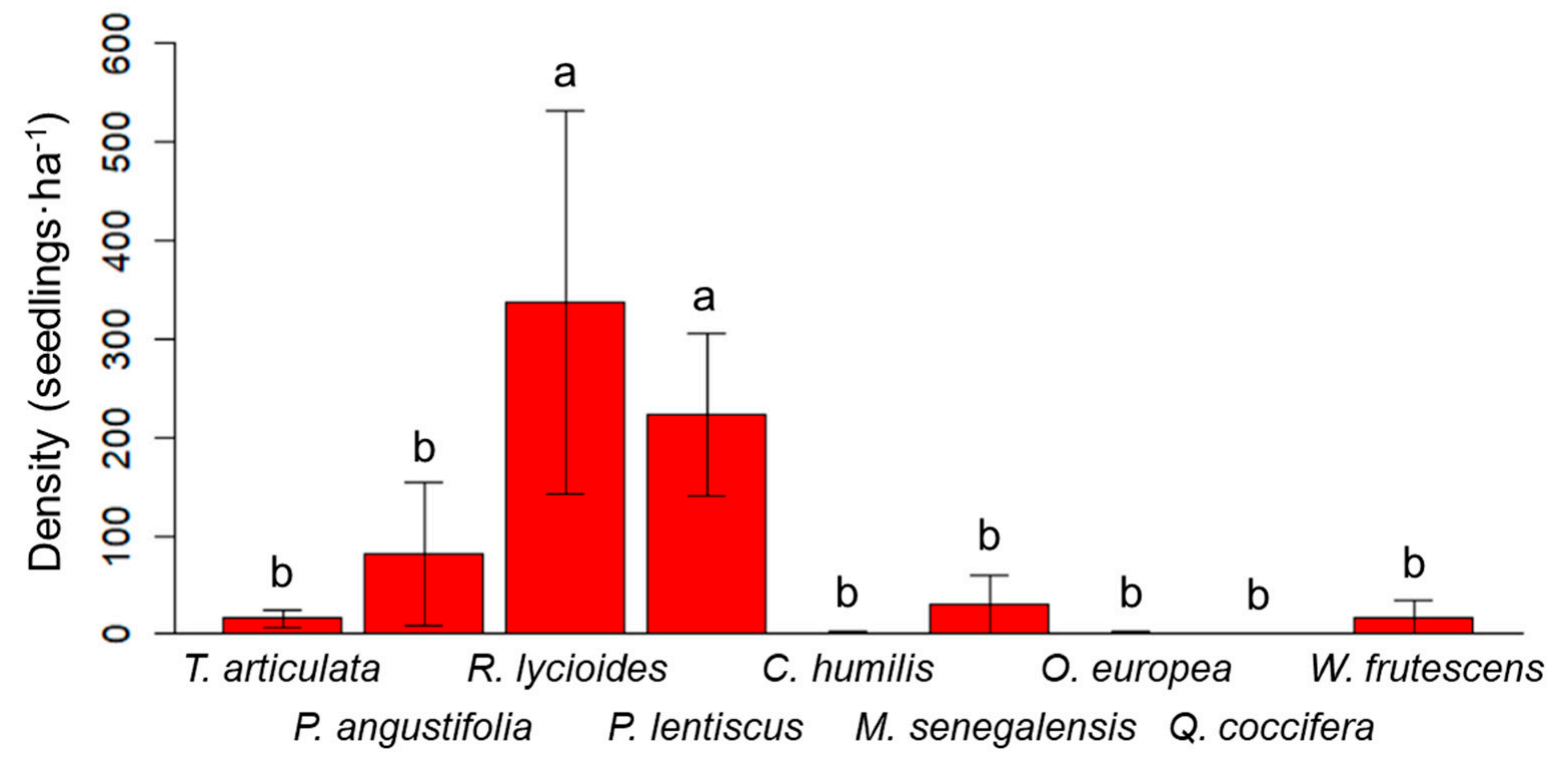

Figure 1. Natural colonization of nine species belonging to the Tetraclinis mixed forest in eight mine tailings within the Cartagena-La Unión mining district in SE Spain. Bars indicate standard errors. Significant differences among species are indicated by different letters (GLM, $p<0.1)$. All the species are monoecious excepting R. lycioides, P. lentiscus and C. humilis.

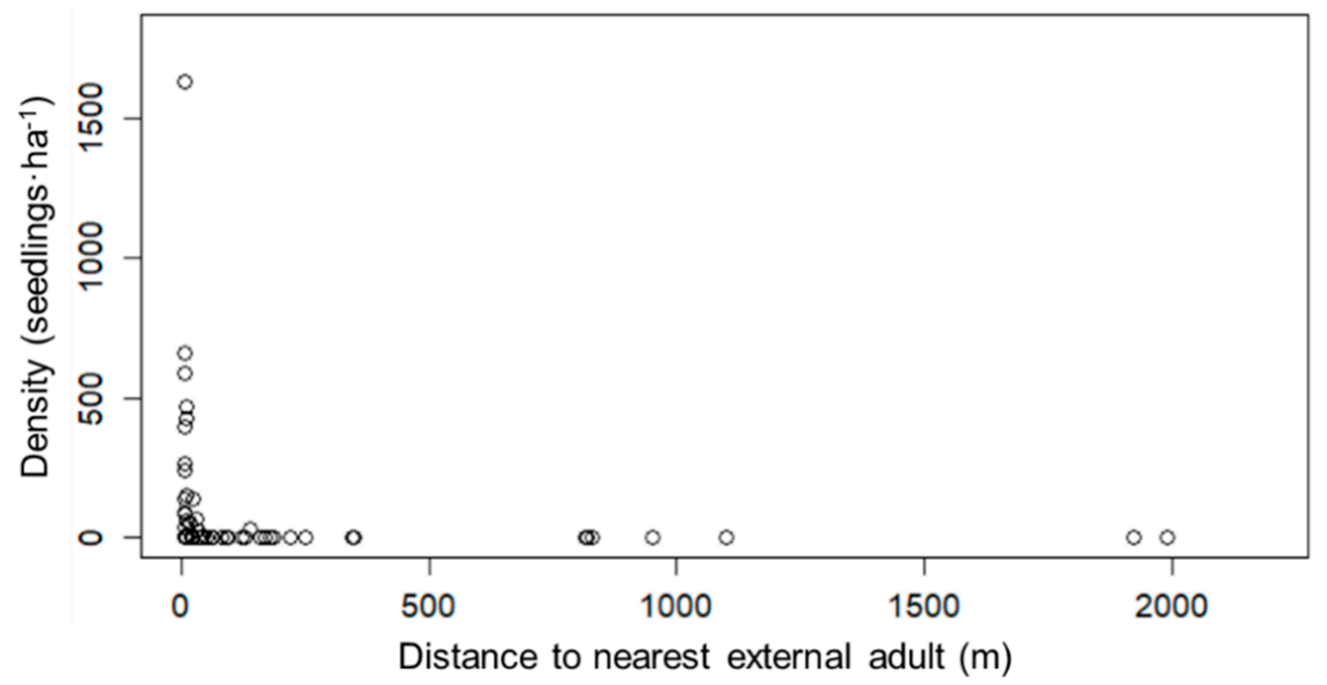

Figure 2. Relationship between the density of naturally-established seedlings within the tailings and the distance from the tailing border to the nearest adult plant growing in the surrounding landscape.

\subsection{Plantation of the Tetraclinis Mixed Forest in a Mine Tailing}

Both the identity of the planted species and the addition of an organic amendment had an effect on plant survival 15 months after the plantation. Survival was above $60 \%$ in all species excepting $W$. frutescens, $M$. senegalensis, O. europea and T. articulata, which showed mean survival above $90 \%$ (Table S3). Taking all species together, plant survival was higher in control plants (93\%) compared to those with an organic amendment (80\%). Individually, at least $O$. europea and $P$. angustifolia showed this negative effect of the organic amendment, with $8 \%$ and $40 \%$ survival reduction.

The organic amendment did not have an effect on the mean size of most planted species, but for T. articulata which was $25 \%$ taller when receiving amendments (Table S5). 
Similarly, the mean trunk diameter was significantly larger in $R$. lycioides and Q. coccifera with amendments.

Leaf macronutrient content (Mantel test, $r=0.033, p=0.169$ ) and metal(oid) bioaccumulation (Mantel, $r=-0.003, p=0.523$ ) in planted individuals did not show spatial autocorrelation, indicating a lack of effect of soil heterogeneity in this respect. The organic amendment significantly increased leaf $\mathrm{N}$ content and reduced the C:N ratio (Table 2, Figure S4). Moreover, plant species identity significantly determined all the macronutrients and the C:N ratio (Figure 3). Species by species, leaf $\mathrm{N}$ content in T. articulata increased in plants with organic amendments (Table 3, Figure S5). P showed contrasted responses in R. lycioides and P. angustifolia and K significantly decreased in Q. coccifera with organic amendments. The leaf $\mathrm{C}: \mathrm{N}$ ratio decreased significantly in T. articulata and $\mathrm{M}$. senegalensis with organic amendments.

Table 2. Statistical effects of species identity, organic amendment, and their interaction on leaf macronutrient and metal(oid) contents in planted individuals. Analysis of deviance of the GLM and probability are indicated with ${ }^{*}(p<0.1){ }^{*}(p<0.05)$, $* *(p<0.01)$ and ${ }^{* * *}(p<0.001)$.

\begin{tabular}{|c|c|c|c|c|c|c|c|}
\hline \multirow{2}{*}{ Factors } & \multicolumn{7}{|c|}{ Macronutrients } \\
\hline & \multicolumn{2}{|c|}{$\mathbf{N}$} & \multicolumn{2}{|l|}{$\mathbf{P}$} & K & \multicolumn{2}{|r|}{$C: N$} \\
\hline Organic Amendment & \multicolumn{2}{|c|}{$5.27 *$} & \multicolumn{2}{|l|}{0.29} & \multicolumn{2}{|l|}{0.72} & $6.34 *$ \\
\hline Species Identity & \multicolumn{2}{|c|}{$4.70^{* * *}$} & \multicolumn{2}{|l|}{$5.12^{* * *}$} & \multicolumn{2}{|l|}{$6.62 * * *$} & $5.14^{* * *}$ \\
\hline Amendment $x$ Species & \multicolumn{2}{|c|}{0.35} & $3.15^{* *}$ & & \multicolumn{2}{|l|}{0.50} & 0.44 \\
\hline \multirow{2}{*}{ Factors } & \multicolumn{7}{|c|}{ Metal(oid)s } \\
\hline & As & $\mathrm{Cd}$ & $\mathrm{Cu}$ & $\mathrm{Fe}$ & Mn & $\mathbf{P b}$ & $\mathrm{Zn}$ \\
\hline Organic Amendment & 0.28 & 0.03 & $5.58 *$ & 0.02 & 0.09 & 0.02 & 0.12 \\
\hline Species Identity & $5.11^{* * *}$ & $9.99 * * *$ & $13.78^{* * *}$ & $5.16^{* * *}$ & $18.91^{* * *}$ & $8.95^{* * *}$ & $4.28^{* * *}$ \\
\hline Amendment $x$ Species & 1.21 & 0.81 & 0.92 & $2.18 *$ & 2.01 & $1.988^{\circ}$ & 0.43 \\
\hline
\end{tabular}

Table 3. Effects of adding organic amendments on leaf macronutrient and metal(oid) contents in the nine planted species. $\downarrow$ and $\uparrow$ indicate significant decrease or increase in amended compared to control plants (GLM; $p<0.05)$.

\begin{tabular}{|c|c|c|c|c|c|c|c|c|c|c|c|}
\hline \multirow{2}{*}{ Species } & \multicolumn{4}{|c|}{ Macronutrients } & \multicolumn{5}{|c|}{ Metal(oid)s } & \multirow[b]{2}{*}{$\mathbf{P b}$} & \multirow[b]{2}{*}{$\mathrm{Zn}$} \\
\hline & $\mathbf{N}$ & $\mathbf{P}$ & $\mathbf{K}$ & $\mathrm{C}: \mathrm{N}$ & As & $\mathrm{Cd}$ & $\mathrm{Cu}$ & $\mathrm{Fe}$ & Mn & & \\
\hline Tetraclinis articulata & $\uparrow$ & & & $\downarrow$ & & & & & & & \\
\hline Rhamnus lycioides & & $\downarrow$ & & & & & $\uparrow$ & & & & \\
\hline Pistacia lentiscus & & & & & & & & & $\downarrow$ & & \\
\hline Olea europaea & & & & & & & $\uparrow$ & & & & \\
\hline Chamaerops humilis & & & & & & & & & & & \\
\hline Maytenus senegalensis & & & & $\downarrow$ & & & $\uparrow$ & & & & \\
\hline $\begin{array}{l}\text { Periploca angustifolia } \\
\text { Quercus coccifera }\end{array}$ & & $\uparrow$ & $\downarrow$ & & & & & $\uparrow$ & $\uparrow$ & $\uparrow$ & \\
\hline
\end{tabular}

The content of metal(oid)s did not respond to the addition of the organic amendment but for $\mathrm{Cu}$, which increased significantly (Table 3, Figure S4). All the metal(oid)s varied with plant species identity (Figure 3), As, $\mathrm{Fe}, \mathrm{Cu}$ and $\mathrm{Pb}$ showing similar patterns with lowest contents in O. europaea and T. articulata and highest in P. angustifolia and R. lycioides. Species by species, $\mathrm{Cu}$ contents significantly increased in $R$. lycioides, O. europaea and $M$. senegalensis with organic amendments (Table 3, Figure S5). Similarly, in P. angustifolia both $\mathrm{Fe}, \mathrm{Mn}$ and $\mathrm{Pb}$ contents increased with organic amendments. 

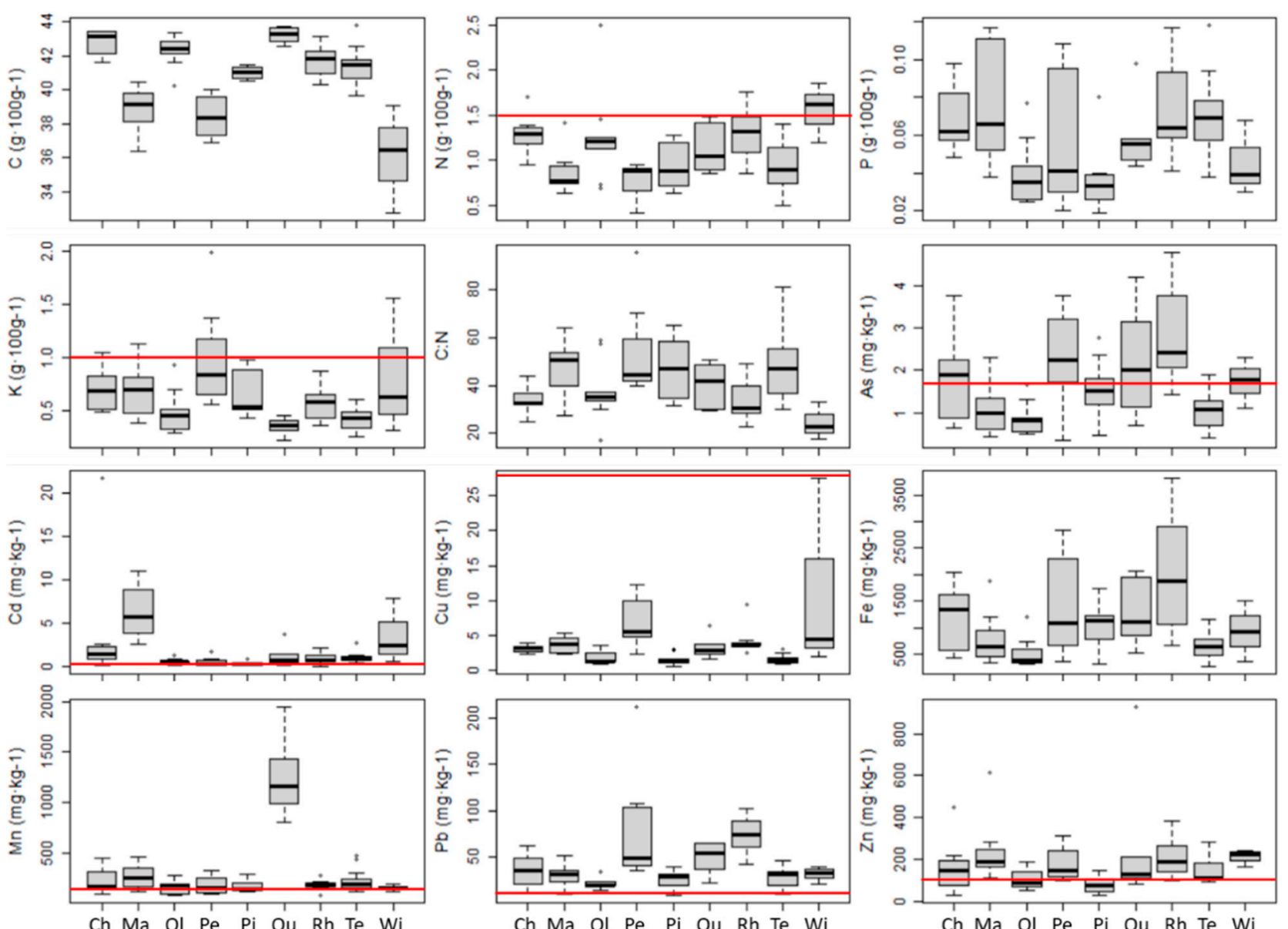

Figure 3. Leaf macronutrient and metal(oid) content in plants from nine species 15 months after plantation. For each boxplot, the horizontal black line indicates the median, the box encompasses from the 25th to the 75th percentile, the whiskers encompass from 10th to 90th percentile and the crosses are outliers. Red lines indicate average normal contents for $\mathrm{N}, \mathrm{P}\left(0.2 \mathrm{~g} \cdot 100 \mathrm{~g}^{-1}\right)$ and K [43] and for As, Cu, Zn, Pb [44], Cd [45], Mn [46] Mn and Fe (140 mg.100 kg $\left.{ }^{-1}\right)$ [47]. Ch = C. humilis, $\mathrm{Ma}=$ M. senegalensis, $\mathrm{Ol}=$ O. europaea var. silvestris, $\mathrm{Pe}=P$. angustifolia, $\mathrm{Pi}=P$. lentiscus, $\mathrm{Qu}=Q$. coccifera, $\mathrm{Rh}=R$. lycioides, $\mathrm{Te}=T$. articulata, $\mathrm{Wi}=W$. frutescens.

\section{Discussion}

Our results indicate that the ancient Tetraclinis mixed forest that used to occupy the study area previous to the mining activity is starting to colonize the abandoned tailings. We detected a contrasted success in plant establishment among our nine target species, seedling densities per unit area differing up to two orders of magnitude. Rey and colleagues [48] also found contrasted probabilities of seed dispersal for two of these species (O. europaea and P. lentiscus), with overall recruitment probabilities of only 0.0036 and 0.0015 . Our results suggest that such low final probabilities might increase together with the proximity of seed-provider adults in the neighborhood, which was a main factor determining natural seedling establishment in our case. Several authors have found that the likelihood of seed arrival is the main determinant of community structure in very different ecosystems [49], although examples for the lack of an effect of the proximity to seed sources are available for instance in tropical forests [50]. In young stressful ecosystems, as those studied here, both geographical barriers to seed dispersal and biotic constraints related with the characteristics and behavior of seed dispersers and predators are important drivers of natural plant establishment [51-53]. In Mediterranean ecosystems, shrubs and trees with fleshy fruits as all of our species excepting T. articulata and P. angustifolia, are mainly dispersed by birds and mammals [54]. Dispersal distances are highly variable depending on the disperser and the dispersed species, though Debussche and colleagues [55] described how most seedlings 
are dispersed $<100 \mathrm{~m}$ from the source in abandoned orchards in the French Mediterranean region. Similarly, Jordano and colleagues [56] determined that small passerines are the principal dispersers in southern Spain, usually dispersing seeds to short distances (roughly $<100 \mathrm{~m}$ ) and mainly into vegetation patches, whereas larger birds and mammals disperse to longer distances and more frequently into open microsites. In our study the mean distance from the tailing border to the nearest adult out of the tailing for zoochorous species was of $120 \pm 118 \mathrm{~m}$, whereas for anemochorous species it was of $285 \pm 131 \mathrm{~m}$. As these distances were marginally different ( $t$-test, $p=0.08$ ) we cannot go in depth about the contrasted mechanisms behind the observed dispersion in wind- and animal-dispersed species here studied, which would require a different experimental approach.

The time required for recruitment since abandonment seems to be highly variable. Debussche and colleagues [55] found that five fleshy-fruit species including P. lentiscus reached a recruitment peak in sub-humid Mediterranean orchards 5-10 years after abandonment. Navarro-Cano and colleagues [13] estimated an establishment probability for $R$. lycioides of 0.6 beneath the nurse Ononis tridentata after 35 years since the establishment in semiarid gypsum outcrops from SE Spain. The mine tailings studied here were abandoned between the seventies and the eighties of the past century. As no adult plants but for some T. articulata and P. lentiscus plants have been found in the area, the natural arrival of the target species seems to have begun several years later. Likely, the muddiness of the original wastes delayed the plant colonization process until they underwent a significant desiccation. Actually, available orthophotographs suggest that halophilous species such as Tamarix canariensis and Phragmites australis, which are typical from coastal salt marshes, were the early colonizers in most tailings. These salt-tolerant species were followed by the xerophilous conifer Pinus halepensis, which in all cases established shaping an external belt to T. canariensis probably to avoid temporary flooding during the rainy season [3]. Our results suggest that $P$. halepensis subsequently acted as a nurse for other species likely through offering perches for seed-dispersing birds. However, the perch effect requires both the nurse reaches a threshold size and it gets a reduction of the edaphic stress below its canopy, which may occur several years after the nurse establishment [13]. These results are in line with those by Zapata and colleagues [57], who found that P. lentiscus and $R$. lycioides tend to establish beneath $P$. halepensis in semiarid abandoned fields. In our case, other woody species such as T. canariensis, Osyris lanceolata and Atriplex halimus might have also served as perches that attracted dispersers. All of them have demonstrated their role as nurse species in the tailings as well as their ability to significantly improve the fertility of the barren mine soils, thus creating favorable regeneration microsites [3]. Ecological restoration of plant communities with high proportion of fleshy-fruit species can promote this plant-animal mutualistic interaction as there is a positive feedback between the number of dispersed seeds and frugivore abundance [58].

The plantation of the nine target species characteristic of the Tetraclinis mixed forest showed an overall survival above $80 \%$ after 15 months with significant differences among species. Contrarily to our expectations, the addition of an organic amendment tended to reduce plant establishment, although this negative effect was only significant in $O$. europaea and P. angustifolia. Our results can be considered successful for most species compared to plantations in other mine tailings. Padilla and colleagues $[59,60]$ reported $60 \%$ survival of T. articulata one year after plantation on schists in an arid area, which was significantly improved when summer irrigation was supplied. These authors obtained survival percentages below ours for P. lentiscus, C. humilis, O. europaea and R. lycioides, again with improved effects when irrigation was added. Vilagrosa and colleagues [61] got similar survival rates to ours for P. lentiscus and $R$. lycioides on marly soils under semiarid conditions after one year, whereas Maestre and colleagues [62] obtained lower survival for P. lentiscus on semiarid soils derived from marls and limestones. Therefore, our results indicate that despite the pollution of the mine tailings, edaphic stress does not impose an extra limitation for the survival of the studied species, at least in the short-term. Rather the sandy loam texture of the soil in tailings [63] and its depth (usually $>5 \mathrm{~m}$ ) would allow 
the accumulation of rainfall and the access of roots. This could explain the high survival observed, though a long-term monitoring of the plantation is required in order to confirm an effective establishment and growth of the studied species.

Plant nutritional status can determine and inform on the ecophysiological response to the plantation environment [64]. The plantation of most of the study species has been seldom assessed in this type of soils. Our results indicate that aboveground nutrient contents are in most cases lower than what is considered physiologically healthy for plants [43]. Our leaf N, P and K contents are similar to those found by Párraga-Aguado and colleagues [63] in wild T. articulata plants from metalliferous tailings in SE Spain. Nevertheless, Achak and colleagues [65] obtained similar N content in samples from an unpolluted forest area in Morocco, hence the nutrient content found in our plants could be within the normal range of variation for the species. For P. lentiscus, we found similar nutrient contents to T. articulata, again very similar to those provided by [66] for N, P and $\mathrm{K}$ from wild plants or for $\mathrm{N}$ and $\mathrm{K}$ by Parra and colleagues [21] in a mesocosm experiment with metal-polluted soils. For O. europaea, our leaf N, P and K levels are similar to those measured by Domínguez and colleagues [67] from planted individuals on polluted soils. The organic amendment applied before planting individuals did not improve the nutritional status in most species, except for leaf $\mathrm{N}$ in T. articulata and P in P. angustifolia. On the contrary, organic amendments had a negative effect on leaf $P$ in R. lycioides and on $\mathrm{K}$ in Q. coccifera. Parra and colleagues [21] found an effect of the organic amendment on $\mathrm{K}$ in several shrubs including P. lentiscus but not on $\mathrm{N}$ and P. Other authors have also found contrasted results depending on the species and the type of organic amendment as showed by $\mathrm{Hu}$ and colleagues [68]. Even accepting that the use of organic wastes can have a short-term positive effect on soil fertility and in some cases on the nutrient uptake in barren tailings as observed by Zornoza and colleagues [17] or Arco-Lázaro and colleagues [69], our results indicate that the effectivity of adding organic amendments to plantation holes is species-dependent. Hu and colleagues [68] considered that poor-nutrient and droughttolerant species might show weaker responses to soil amendments. Likely, plant traits related to drought avoidance can explain these contrasted results. For instance, P. lentiscus and $Q$. coccifera have contrasted water-saving strategies [61], which could also affect their nutrient uptake ability and eventually induce nutrient deficits in some species [5].

Ideal target species for plantation in mine tailings must not only be metal-tolerant but also expose a low aboveground metal(oid) bioaccumulation that minimizes metal transfer to the food chain $[1,11,29]$. In our plantation, the bioaccumulation was quite variable among species though most of them had contents above the normal levels for most metal(oid)s excepting $\mathrm{Cu}$ [44-47]. This metal shows a low solubility at neutral-alkaline $\mathrm{pH}$ as in our tailing [70]. These results would paradoxically prevent the use of these key species of the Tetraclinis mixed forest for restoring the tailings, despite we demonstrated that wild plants are slowly colonizing the mining structures and these species are easily established by planting. However, more than three decades since mining abandonment only $10 \%$ of the 89 tailings in the area have been rehabilitated to some extent due to the expensiveness of an effective soil sealing. In this way, a cheaper solution to decrease the aerial and run-off movement of pollutants might include phytoestabilization by means of local metal-tolerant species [26,27]. However, our data underline the need of selecting plants with low bioaccumulation ability. We found that $O$. europaea was the species that showed lower contents among the nine target species, though at least $\mathrm{Fe}$ and $\mathrm{Pb}$ were slightly above the normal levels, followed by T. articulata. On the contrary, Q. coccifera and $R$. lycioides showed the highest metal(oid) contents in most cases. Leaf $\mathrm{As}, \mathrm{Pb}$ and $\mathrm{Zn}$ contents in O. europaea were higher than those found by Domínguez and colleagues [67] in the same species seven years after plantation with organic amendments on polluted soils in SW Spain. Nevertheless, only leaf $\mathrm{Pb}$ in our O. europaea plants was above normal levels according to Kabata-Pendias [44]. The potential use of T. articulata is more controversial as this species bioaccumulated $\mathrm{Cd}, \mathrm{Pb}$ and $\mathrm{Zn}$ above the normal levels. Due to this ability, Disante and colleagues [71] suggested to be cautious when using this species in restoration projects on 
metal-polluted soils. Again, we must face restoration of the Tetraclinis mixed forest in its main location in continental Europe dealing with the paradox that the management of the key species of this forest entails antagonistic aims between biodiversity conservation and environmental well-being.

The organic amendment that we added in the bottom of plantation holes allowed a cost cut together with a reduction of the carbon footprint because its local precedence. Nevertheless, it had a low quality due to a high metal content and EC. This is considered a contraindication for amendment of agricultural soils [39] though accepted for forest soils [40]. Our amendment increased $\mathrm{Cu}$ uptake in three species but still keeping the contents below toxic levels. Something similar happened with P. angustifolia regarding Fe and $\mathrm{Pb}$. On the contrary, $\mathrm{Mn}$ was the only metal that increased above the normal levels in this species 15 months after plantation. This increase in metal bioaccumulation in some of our species after amendment addition could be explained as the consequence of addition of organic matter with a high proportion of mobile fractions (as supposed for our composted waste), which induces metal bioavailability [11,24,72]. Nevertheless, just a long-term monitoring will allow to determine if these effects persist once the planted species explore deeper soil at the adult stage. Other rehabilitation programs have successfully decreased metal mobility by adding carbonate-based amendments in tailings with acidic soils [17]. In our case, the tailing had an average $\mathrm{pH}$ of $7.7 \pm 0.2$, which might keep immobilized most metal(oid)s except for $\mathrm{Cd}$ and $\mathrm{Pb}$ [70]. Kohler and colleagues [73] tested the usefulness of a compost with similar properties to establish a legume shrub on polluted soils under controlled conditions. They determined that its effectiveness was dependent on the dose of the amendment. It is likely that adding organic amendment in a high proportion as here applied partially contributed to increase mobilization, which would obligate to reconsider the dose of organic matter supply in future restoration programmes in the area.

\section{Conclusions}

The establishment of the Tetraclinis mixed forest in semiarid Mediterranean mining areas with high metal(oid)s contents seems feasible by sapling plantation. Most species successfully respond to the establishment in the short-term. Nevertheless, a medium- to long-term monitoring program is necessary to confirm the high plant survival that we recorded and follow the metal bioaccumulation and potential transfer to the food web. Overall, adding organic amendments does not imply a significant benefit for the plant establishment of most studied species, hence it is not considered necessary in restoration programs focused on the establishment of the Tetraclinis mixed forest in semiarid tailings.

Supplementary Materials: The following are available online at https:/ /www.mdpi.com/article/10 $.3390 /$ f12050548/s1, Table S1. Geographical location (UTM coordinates within the 30S grid zone), area, approximate year of abandonment and current plant cover of the eight studied mine tailings in the Cartagena-La Unión Mining District (Murcia, Spain). Table S2. Analyses of deviance of the effects of distance to the nearest external adult, soil fertility and metal(oid) contents on natural seedling density. Significant results are indicated in bold type (GLM, $p<0.05)$. Results for M. senegalensis, $O$. europaea, $Q$. coccifera and $W$. frutescens are not shown due to the absence of sufficient observations in most tailings. Table S3. Seedling survival (\%) of planted species 15 months after plantation. Significant differences between between control plants and those receiving organic amendments are shown in bold type (GLM, $\left.{ }^{*} p<0.05\right)$. Table S4. Mean height and trunk diameter in planted individuals 15 months after plantation. Asterisks indicate significant differences between control plants and those receiving organic amendments $(\mathrm{GLM}, * p<0.05)$. Figure S1. Overview and details of the natural colonization in some tailings of the Cartagena-La Unión mining district (SE Spain). (A) Contact line between the Tetraclinis mixed forest on natural soils on the left and the emerging one on a mine tailing on the right side in the study area. (B) a Mine tailing with a very low plant cover shaped by a perennial grassland and an incipient patchy shrubland. (C) A detail of two saplings belonging to P. lentiscus and T. articulata (red arrows). (D) Two adult M. senegalensis and P. angustifolia (red arrows) on the border of a tailing. Figure S2. Images of the plantation in the tailing. (A) previous view. (B) detail of the composted waste. (C) an amended hole. (D) subsequent plantation of a T. articulata. 
(E) A sapling of P. angustifolia protected with anti-herbivore mesh. Saplings of M. senegalensis (F), W. frutescens $(\mathrm{G})$ and O. europaea $(\mathrm{H})$. General view of the plantation (I). Figure S3. PCA results for soil fertility (left) and metal(oid) content (right). The plot depicts the first and second principal components and their explained variance are given in parentheses. Figure S4. Leaf macronutrient and metal(oid) content 15 months after plantation in control plants $(\mathrm{C})$ and plants receiving organic amendments (OA). Figure S5. Leaf macronutrient and metal(oid) content in eight species belonging to the Tetraclinis mixed forest 15 months after plantation in control plants (C) and plants receiving an organic amendment (OA).

Author Contributions: J.A.N.-C. conceived the research, developed the methodology and wrote a first draft, J.A.N.-C., M.B.O. and M.G. collected field data, contributed to the analyses and wrote the final manuscript. All authors have read and agreed to the published version of the manuscript.

Funding: This study was funded by the LIFE Tetraclinis European Project (LIFE13 NAT/ES/000436). M.B. Oná was awarded with a MAEC-AECID grant from the Ministry of Foreign Affairs and Cooperation of Spain. J.A. Navarro-Cano was supported by the Programa Ramón y Cajal (Ministerio de Ciencia e Innovación, Spanish Government).

Acknowledgments: We acknowledge the trust and support of Fundación sierra Minera. We thank the help of ANSE and Dirección General del Medio Natural de la Región de Murcia. J.M. Escarabajal, G. Gutiérrez, D. López, D.A. Rodríguez, B. López, A.H. Montero and B. Oreja contributed to the field work. M.M. Delgado (INIA) helped with soil analyses. We acknowledge F.C. Fuentes Narváez his authorization to carry out this work on land of his property.

Conflicts of Interest: The authors declare no conflict of interest.

\section{References}

1. Metsaranta, J.M.; Beauchemin, S.; Langley, S.; Tisch, B.; Dale, P. Assessing the Long-Term Ecosystem Productivity Benefits and Potential Impacts of Forests Re-Established on a Mine Tailings Site. Forests 2018, 9, 707. [CrossRef]

2. Panagos, P.; Van Liedekerke, M.; Yigini, Y.; Montanarella, L. Contaminated sites in Europe: Review of the current situation based on data collected through a European network. J. Environ. Public Health 2013, 2013, 158764. [CrossRef] [PubMed]

3. Navarro-Cano, J.A.; Verdú, M.; Goberna, M. Trait-based selection of nurse plants to restore ecosystem functions in mine tailings. J. Appl. Ecol. 2018, 55, 1195-1206. [CrossRef]

4. Colin, Y.; Goberna, M.; Verdú, M.; Navarro-Cano, J.A. Successional trajectories of soil bacterial communities in mine tailings: The role of plant functional traits. J. Environ. Manag. 2019, 241, 284-292. [CrossRef] [PubMed]

5. Oreja, B.; Goberna, M.; Verdú, M.; Navarro-Cano, J.A. Constructed pine log piles facilitate plant establishment in mining drylands. J. Environ. Manag. 2020, 271, 111015. [CrossRef] [PubMed]

6. Beauchemin, S.; Clement, J.S.; Thibault, Y.; Langley, S.; Gregorich, E.G.; Tisch, B. Geochemical stability of acid-generating pyrrhotite tailings 4 to 5 years after addition of oxygen-consuming organic covers. Sci. Totol Environ. 2018, 645, 1643-1655. [CrossRef]

7. Pietrzykowski, M.; Daniels, W.L. Estimation of carbon sequestration by pine (Pinus sylvestris L.) ecosystems developing on reforested post-mining sites in Poland on differing mine soil substrates. Ecol. Eng. 2014, 73, 209-218. [CrossRef]

8. Pietrzykowski, M.; Krzaklewski, K. Potential for carbon sequestration in reclaimed mine soil on reforested surface mining areas in Poland. Nat. Sci. 2010, 2, 1015-1021. [CrossRef]

9. Rodrigue, J.A.; Burger, J.A.; Oderwald, R.G. Forest productivity and commercial value of pre-law reclaimed mined land in the Eastern United States. North. J. App. For. 2002, 19, 106-114. [CrossRef]

10. Williams, D.J.; Currey, N.A. Engineering closure of an open pit gold operation in a semi-arid climate. Int. J. Surf. Min. Reclam. Environ. 2002, 16, 270-288. [CrossRef]

11. Mendez, M.O.; Maier, R.M. Phytostabilization of mine tailings in arid and semiarid environments-An emerging remediation technology. Environ. Health Perspect. 2008, 116, 278-283. [CrossRef]

12. Martínez-Martínez, S.; Zornoza, R.; Gabarrón, M.; Gómez-Garrido, M.; Rosales, R.M.; Muñoz, M.A.; Gómez-López, M.D.; Soriano-Disla, J.M.; Faz, A.; Acosta, J.A. Is aided phytostabilization a suitable technique for the remediation of tailings? Eur. J. Soil Sci. 2019, 70, 862-875. [CrossRef]

13. Navarro-Cano, J.A.; Goberna, M.; Valiente-Banuet, A.; Verdu, M. Same nurse but different time: Temporal divergence in the facilitation of plant lineages with contrasted functional syndromes. Funct. Ecol. 2016, 30, 1854-1861. [CrossRef]

14. Gómez-Ros, J.M.; Garcia, G.; Peñas, J.M. Assessment of restoration success of former metal mining areas after 30 years in a highly polluted Mediterranean mining area: Cartagena-La Unión. Ecol. Eng. 2013, 57, 393-402. [CrossRef]

15. Shuman, L.M. Organic waste amendments effect on zinc fractions of two soils. J. Environ. Qual. 1999, 28, 1442-1447. [CrossRef]

16. Walker, D.J.; Clemente, R.; Bernal, M.P. Contrasting effects of manure and compost on soil pH, heavy metal availability and growth of Chenopodium album L. in a soil contaminated by pyritic mine waste. Chemosphere 2004, 57, 215-224. [CrossRef] 
17. Zornoza, R.; Faz, A.; Carmona, D.M.; Martínez-Martínez, S.; Acosta, J.A. Plant cover and soil biochemical properties in a mine tailing pond five years after application of marble wastes and organic amendments. Pedosphere 2012, 22, 22-32. [CrossRef]

18. Park, J.H.; Lamb, D.; Paneerselvam, P.; Choppala, G.; Bolan, N.; Chung, J.W. Role of organic amendments on enhanced bioremediation of heavy metal (loid) contaminated soils. J. Hazard. Mater. 2011, 185, 549-574. [CrossRef] [PubMed]

19. Tordof, G.M.; Baker, A.J.M.; Willis, A.J. Current approaches to the revegetation and reclamation of metalliferous mine wastes Chemosphere 2000, 41, 219-228. [CrossRef]

20. Pond, A.P.; White, S.A.; Milczarek, M.; Thompson, T.L. Accelerated weathering of biosolid-amended copper mine tailings. J. Environ. Qual. 2005, 34, 1293-1301. [CrossRef]

21. Parra, A.; Zornoza, R.; Conesa, E.; Faz, A.; Gómez-López, M.D. Nutritional status and its interaction with soil properties and trace elements in six Mediterranean shrub species grown in reclaimed pyritic tailings. Ecol. Eng. 2017, 109, 25-34. [CrossRef]

22. Bainbridge, D.A. A Guide for Desert and Dryland Restoration: New Hope for Arid Lands; Island Press: Washington, DC, USA, 2007.

23. Hou, X.; Liu, S.; Zhao, S.; Beazley, R.; Cheng, F.; Wu, X.; Xu, J.; Dong, S. Selection of suitable species as a key factor for vegetation restoration of degraded areas in an open-pit manganese-ore mine in Southern China using multivariate-analysis methods. Land Degrad. Dev. 2019, 30, 942-950. [CrossRef]

24. Párraga-Aguado, I.; González-Alcaraz, M.N.; Álvarez-Rogel, J.; Jiménez-Cárceles, F.J.; Conesa, H.M. The importance of edaphic niches and pioneer plant species succession for the phytomanagement of mine tailings. Environ. Pollut. 2013, 176, 134-143. [CrossRef] [PubMed]

25. Navarro-Cano, J.A.; Goberna, M.; Verdú, M. Using plant functional distances to select species for restoration of mining sites. J. Appl. Ecol. 2019, 56, 2353-2362. [CrossRef]

26. Conesa, H.M.; Schulin, R. The Cartagena-La Unión mining district (SE Spain): A review of environmental problems and emerging phytoremediation solutions after fifteen years research. J. Environ. Monit. 2010, 12, 1225-1233. [CrossRef] [PubMed]

27. Álvarez-Rogel, J.; Peñalver-Alcalá, A.; Jiménez-Cárceles, F.J.; Tercero, M.C.; González-Alcaraz, M.N. Evidence supporting the value of spontaneous vegetation for phytomanagement of soil ecosystem functions in abandoned metal(loid) mine tailings. Catena 2021, 201, 105191. [CrossRef]

28. Lee, J.S.; Chon, H.T. Exposure assessment of heavy metals on abandoned metal mine areas by ingestion of soil, crop plant and groundwater. J. Phys. IV 2003, 107, 757-760, EDP sciences. [CrossRef]

29. González-Alcaraz, M.N.; van Gestel, C.A.M. Climate change effects on enchytraeid performance in metal-polluted soils explained from changes in metal bioavailability and bioaccumulation. Environ. Res. 2015, 142, 177-184. [CrossRef]

30. Gutiérrez, M.; Mickus, K.; Camacho, L.M. Abandoned PbZn mining wastes and their mobility as proxy to toxicity: A review. Sci. Total Environ. 2016, 565, 392-400. [CrossRef]

31. Blondet, I.; Schreck, E.; Viers, J.; Casas, S.; Jubany, I.; Bahí, N.; Zouiten, C.; Dufréchou, G.; Freydier, R.; Galy-Lacaux, C.; et al. Atmospheric dust characterisation in the mining district of Cartagena-La Unión, Spain: Air quality and health risks assessment. Sci. Total Environ. 2019, 693, 133496. [CrossRef]

32. Wang, P.; Sun, Z.; Hu, Y.; Cheng, H. Leaching of heavy metals from abandoned mine tailings brought by precipitation and the associated environmental impact. Sci. Total Environ. 2019, 695, 133893. [CrossRef]

33. Esteve-Selma, M.A.; Martínez-Fernández, J.; Hernández-García, I.; Montávez, J.P.; López-Hernández, J.J.; Calvo, J.F. Potential effects of climatic change on the distribution of Tetraclinis articulata, an endemic tree from arid Mediterranean ecosystems. Clim. Chang. 2012, 113, 663-678. [CrossRef]

34. European Commission. Interpretation Manual of European Union Habitats; EC DG Environment: Brussels, Belgium, 2013.

35. Esteve-Selma, M.A.; Moya-Pérez, J.M.; Navarro-Cano, J.A. Manual de Evaluación y Gestión del Hábitat 9570: Bosques de Tetraclinis Articulata; Dirección General del Medio Natural: Murcia, Spain, 2019; p. 87.

36. Navarro-Cano, J.A.; Goberna, M.; Valiente-Banuet, A.; Verdú, M. Phenotypic structure of plant facilitation networks. Ecol. Lett. 2021, 24, 509-519. [CrossRef]

37. Navarro-Cano, J.A.; Verdú, M.; García, C.; Goberna, M. What nurse shrubs can do for barren soils: Rapid productivity shifts associated with a 40 years ontogenetic gradient. Plant. Soil 2015, 388, 197-209. [CrossRef]

38. Prikhodko, V.E.; Azarenko, Y.A.; Shayakhmetov, M.R.; Tishkin, A.A.; Gorbunov, V.V.; Pivovarova, E.G. Reconstruction of the climate of the Medieval Epoch based on soil and geochemical studies of kurgans of the Srostki Culture in the South of Western Siberia. Eurasian Soil Sci. 2020, 53, 267-282. [CrossRef]

39. Crommentuijn, T.; Polder, M.D.; van de Plassche, E.J. Maximum Permissible Concentrations and Negligible Concentrations for Metals, Taking Background Concentrations into Account; RIVM Report Number 601501001; National Institute of Public Health and the Environment Bilthoven: Bilthoven, The Netherlands, 1997; p. 260. Available online: https://rivm.openrepository.com/handle/ 10029/10113 (accessed on 27 January 2021).

40. Aguilar, J.; Dorronsoro, C.; Galán, E.; Gómez Ariza, J.L. Los criterios y estándares para declarar un suelo como contaminado en Andalucía y la metodología y técnica de toma de muestras y análisis para su investigación. In Investigación y Desarrollo Medioambiental en Andalucía; OTRI. Universidad de Sevilla: Sevilla, Spain, 1999; p. 253. Available online: http://www.ugr.es/ $\sim\{\}$ fjmartin/INFORMES/Criterios\%20y\%20estandares.pdf (accessed on 28 January 2021).

41. R Core Team. R: A Language and Environment for Statistical Computing; R Foundation for Statistical Computing: Vienna, Austria, 2020; Available online: https:/ / www.r-project.org/ (accessed on 20 September 2020). 
42. Oksanen, J.; Guillaume, F.; Friendly, M.; Kindt, R.; Legendre, P.; McGlinn, D.; Minchin, P.R.; O’Hara, R.B.; Simpson, G.L.; Solymos, P.; et al. Vegan: Community Ecology Package. R Package Version 2.5-6. Available online: https://CRAN.Rproject.org/package= vegan (accessed on 1 October 2020).

43. Azcon-Bieto, J.; Talón, M. Fundamentos de Fisiología Vegetal; McGraw-Hill: Barcelona, Spain, 2000.

44. Kabata-Pendias, A. Trace Elements in Soils and Plants, 3rd ed.; CRC Press LLC: Boca Raton, FL, USA, 2001.

45. Nazar, R.; Iqbal, N.; Masood, A.; Khan, M.I.R.; Syeed, S.; Khan, N.A. Cadmium toxicity in plants and role of mineral nutrients in its alleviation. Am. J. Plant. Sci. 2012, 3, 1476-1489. [CrossRef]

46. Li, J.; Jia, Y.; Dong, R.; Huang, R.; Liu, P.; Li, X.; Wang, Z.; Liu, G.; Chen, Z. Advances in the mechanisms of plant tolerance to manganese toxicity. Int. J. Mol. Sci. 2019, 20, 5096. [CrossRef]

47. Anjum, N.A.; Singh, H.P.; Khan, M.I.R.; Masood, A.; Per, T.S.; Negi, A.; Batish, D.R.; Khan, N.A.; Duarte, A.C.; Pereira, E.; et al. Too much is bad-An appraisal of phytotoxicity of elevated plant-beneficial heavy metal ions. Environ. Sci. Pollut. Res. 2015, 22, 3361-3382. [CrossRef]

48. Rey, P.J.; Alcántara, J.M. Recruitment dynamics of a fleshy-fruited plant (Olea europaea): Connecting patterns of seed dispersal to seedling establishment. J. Ecol. 2000, 88, 622-633. [CrossRef]

49. Young, T.P.; Petersen, D.A.; Clary, J.J. The ecology of restoration: Historical links, emerging issues and unexplored realms. Ecol. Lett. 2005, 8, 662-673. [CrossRef]

50. Hardesty, B.D.; Hubbell, S.P.; Bermingham, E. Genetic evidence of frequent long-distance recruitment in a vertebrate-dispersed tree. Ecol. Lett. 2006, 9, 516-525. [CrossRef]

51. Nathan, R.; Muller-Landau, H.C. Spatial patterns of seed dispersal, their determinants and consequences for recruitment. Trends Ecol. Evol. 2000, 15, 278-285. [CrossRef]

52. Walker, L.R.; Del Moral, R. Primary Succession and Ecosystem Rehabilitation; Cambridge University Press: Cambridge, UK, 2003.

53. Aradottir, A.L.; Halldorsson, G. Colonization of woodland species during restoration: Seed or safe site limitation? Rest. Ecol. 2008, 26, S73-S83. [CrossRef]

54. Herrera, C.M. Plant-vertebrate seed dispersal systems in the Mediterranean: Ecological, evolutionary, and historical determinants. Ann. Rev. Ecol. System. 1995, 26, 705-727. [CrossRef]

55. Debussche, M.; Escarré, J.; Lepart, J. Ornithochory and plant succession in Mediterranean abandoned orchards. Vegetatio 1982, 48, 255-266.

56. Jordano, P.; García, C.; Godoy, J.A.; García-Castaño, J.L. Differential contribution of frugivores to complex seed dispersal patterns. Proc. Nat. Acad. Sci. USA 2007, 104, 3278-3282. [CrossRef]

57. Zapata, V.M.; Robledano, F.; Ramos, V.; Martínez-López, V. Bird-mediated seed dispersal of fleshy fruits of Mediterranean shrubs in semiarid forest patches: The role of Pinus halepensis Miller trees as seed receptors. Plant. Ecol. 2014, 215, 1337-1350. [CrossRef]

58. McConkey, K.R.; Prasad, S.; Corlett, R.T.; Campos-Arceiz, A.; Brodie, J.F.; Rogers, H.; Santamaria, L. Seed dispersal in changing landscapes. Biol. Conserv. 2012, 146, 1-13. [CrossRef]

59. Padilla, F.M.; Pugnaire, F.I. El uso de especies arbustivas para la restauración de la cubierta vegetal en ambientes semiáridos. Cuad. Soc. Esp. Cie. For. 2004, 17, 103-107.

60. Padilla, F.M.; Ortega, R.; Sánchez, J.; Pugnaire, F.I. Rethinking species selection for restoration of arid shrublands. Basic Appl. Ecol. 2009, 10, 640-647. [CrossRef]

61. Vilagrosa, A.; Caturla, R.N.; Hernández, N.; Cortina, J.; Bellot, J.; Vallejo, V.R. Reforestación en ambiente semiárido del sureste peninsular. Resultados de las investigaciones desarrolladas para optimizar la supervivencia y el crecimiento de especies autóctonas. In Montes para la sociedad del nuevo milenio. III Congreso Forestal Español. Junta Andal. Cons. Medio Ambiente 2001, $4,5-10$.

62. Maestre, F.T.; Bautista, S.; Cortina, J.; Bellot, J. Potential for using facilitation by grasses to establish shrubs on a semiarid degraded steppe. Ecol. Appl. 2001, 11, 1641-1655. [CrossRef]

63. Párraga-Aguado, I.; Querejeta, J.J.; González-Alcaraz, M.N.; Jiménez-Cárceles, F.J.; Conesa, H.M. Usefulness of pioneer vegetation for the phytomanagement of metal(loid)s enriched tailings: Grasses vs. shrubs vs. trees. J. Environ. Manag. 2014, 133, 51-58 [CrossRef] [PubMed]

64. Oliet, J.A.; Puértolas, J.; Planelles, R.; Jacobs, D.F. Nutrient loading of forest tree seedlings to promote stress resistance and field performance: A Mediterranean perspective. New For. 2013, 44, 649-669. [CrossRef]

65. Achak, N.; Romane, A.; Alifriqui, M.; Markouk, M. Chemical composition, organic and mineral contents of leaves of Tetraclinis articulata (Vahl) masters from the Tensift-Al Haouz, Marrakech region (Morocco). J. Essent. Oil-Bear. Plants 2009, 12, 198-204. [CrossRef]

66. Párraga-Aguado, I.; González-Alcaraz, M.N.; Álvarez-Rogel, J.; Conesa, H.M. Assessment of the employment of halophyte plant species for the phytomanagement of mine tailings in semiarid areas. Ecol. Eng. 2014, 71, 598-604. [CrossRef]

67. Domínguez, M.T.; Marañón, T.; Murillo, J.M.; Schulin, R.; Robinson, B.H. Nutritional status of Mediterranean trees growing in a contaminated and remediated area. Water Air Soil Poll. 2010, 205, 305-321. [CrossRef]

68. Hu, Y.L.; Mgelwa, A.S.; Singh, A.N.; Zeng, D.H. Differential responses of the soil nutrient status, biomass production, and nutrient uptake for three plant species to organic amendments of placer gold mine-tailing soils. Land Degrad. Dev. 2018, 29, 2836-2845. [CrossRef] 
69. Arco-Lázaro, E.; Martínez-Fernández, D.; Bernal, M.P.; Clemente, R. Response of Piptatherum miliaceum to co-culture with a legume species for the phytostabilisation of trace elements contaminated soils. J. Soils Sediments 2017, 17, 1349-1357. [CrossRef]

70. Ross, S.M. Retention, transformation and mobility of toxic metals in soils. In Toxic Metals in Soil-Plant Systems; Ross, S.M., Ed.; John Wiley and Sons Ltd.: Chichester, UK, 1994; pp. 63-152.

71. Disante, K.B.; Fuentes, D.; Cortina, J. Sensitivity to zinc of Mediterranean woody species important for restoration. Sci. Total Environ. 2010, 408, e2225. [CrossRef]

72. Almås, Å.; Singh, B.R.; Salbu, B. Mobility of cadmium-109 and zinc-65 in soil influenced by equilibration time, temperature, and organic matter. J. Environ. Qual. 1999, 28, 1742-1750. [CrossRef]

73. Kohler, J.; Caravaca, F.; Azcón, R.; Díaz, G.; Roldán, A. The combination of compost addition and arbuscular mycorrhizal inoculation produced positive and synergistic effects on the phytomanagement of a semiarid mine tailing. Sci. Total Environ. 2015, 514, 42-48. [CrossRef] [PubMed] 